\title{
Evaluation of Redox Potential of Herbal Toothpastes: An in-vitro Study
}

\author{
Chaithra Lakshmi V ${ }^{1 *}$, Nishmitha Hegde ${ }^{2}$, Nidarsh D Hegde ${ }^{3}$, Suchetha Kumari ${ }^{4}$, Mithra N Hegde ${ }^{5}$, \\ Nireeksha Shetty ${ }^{6}$ \\ ${ }^{1}$ Junior Research Fellow, AB Shetty Memorial Institute of Dental Sciences, Mangaluru, Karnataka, India \\ ${ }^{2}$ MDS Student, AB Shetty Memorial Institute of Dental Sciences, Mangaluru, Karnataka, India \\ ${ }^{3}$ Principal, JNIMS College, Porompat, Imphal- East, Manipur, India \\ ${ }^{4}$ Scientific Officer, Central Research Laboratory, KSHEMA, Mangaluru, Karnataka, India \\ ${ }^{5}$ Vice Principal and Head, Department of Conservative Dentistry and Endodontics, AB Shetty Memorial \\ Institute of Dental Sciences, Mangaluru, Karnataka, India
}
${ }^{6}$ Department of Conservative Dentistry and Endodontics, A.B. Shetty Memorial Institute of Dental Sciences, Mangaluru, Karnataka, India

\begin{abstract}
*Corresponding Author: Chaithra Lakshmi V, Junior Research Fellow, AB Shetty Memorial Institute of Dental Sciences, Mangaluru, Karnataka, India; Email: chaithralakshmivittal@gmail.com
\end{abstract}

Received Date: 25-01-2021; Accepted Date: 24-02-2021; Published Date: 04-03-2021

Copyright $^{\circledR} 2021$ by Chaithra LV, et al. All rights reserved. This is an open access article distributed under the terms of the Creative Commons Attribution License, which permits unrestricted use, distribution and reproduction in any medium, provided the original author and source are credited.

\begin{abstract}
Aim: To evaluate the reducing potential of herbal toothpastes in comparison with a non-herbal toothpaste.

Methodology: In-vitro analysis was conducted among seven herbal toothpaste groups (numbered from 1-7) and one non-herbal toothpaste (group 8). The toothpastes were diluted with distilled water, filtered, and the clear solution was taken as a test sample. Evaluation of reducing potential was done by Dinitrophenylhydrazine (DNPH) method. The results were obtained using the ANOVA test.
\end{abstract}

Result: Group 3 (Dabur dant rakshak) of the herbal tooth pastes showed the highest reducing potential with a mean value of 4.46 followed by group 5 (Patanjali Dantkanti), group 2 (Dabur red gel), group 1 (Dabur Red toothpaste), group 6 (Colgate Swarna Vedshakti), group 4 (Dabur 
babool ayurvedic), group 7 (Dabur meswak) and the least mean value was observed in nonherbal group 8 (Colgate Strong teeth).

Clinical Significance: The imbalance between antioxidants and free radicals leads to pathologies in the oral cavity such as dental caries, periodontitis, oral mucosal lesions including some pre-cancerous and cancerous lesions. The medicated toothpastes containing herbal products with increasing redox potential and decreasing free radical activities would be beneficial in enhancing oral health.

\section{Keywords}

Redox; Toothpastes; Oral Cavity; Antioxidant; Free Radicals; Dinitrophenylhydrazine; Oral Health

\section{Introduction}

The human oral cavity contains a number of different habitats for the growth of oral microbes. The habitats affect the teeth, gingival sulcus, tongue, hard and soft palate, tonsils. As well the oral cavity acts as the tube which connects the outside and the digestive tract and respiratory tract of the human body, thus providing the appropriate space for the colonization of microorganisms [1].

Oral microbes play a vital role in deteriorating oral health status and increasing the risk of dental caries, plaque formation and deposition, which aggravates the periodontal infection and induces bone loss. The active opportunistic pathogens that reside on the surface of the tooth, causing enamel demineralization, and further dentinal degradation, causes dental caries. The tooth and the structure surrounding it are of prime importance in normal functions like mastication and speech. The oral hygiene maintenance in many individuals is customary and not given enough importance, which over a long period leads to an increase in plaque formation and deposition causing poor oral hygiene. The usage of toothpaste and toothbrush is used as a prophylactic method, and not much attention is given to the composition of toothpaste and its effect on oral health [2].

The anaerobic gram-negative bacteria which are associated with periodontal disease require a low redox potential for their growth. The rise in redox potential in the oral cavity is a physiological route for the reduction of periodontal disease. It could involve the delivery of either oxygen or oxygen radicals to a site, or of compounds which increase the local redox potential [3]. 
Free radicals promote beneficial oxidation that generates energy and kills bacterial invaders. However, excess free radicals can produce a harmful oxidation that can damage cell membranes and causes cell death. They are highly toxic, and if allowed to accumulate, they can destroy all the macromolecules, such as proteins, lipids, and mitochondrial and nuclear DNA molecules of the cells, causing severe oxidative stress [4]. Antioxidants are organic molecules that will eliminate the free radicals generated by the metabolic reaction in our body. Antioxidants, play a significant role in identifying several free radicals, which are very harmful to the cells and tissues. Excess generation of free radicals may overwhelm natural cellular antioxidant defenses leading to oxidation and further contributing to cellular functional impairment [5].

Conventional toothpaste with chemical agents is regularly used in households as an agent to maintain oral hygiene. They contain chemical agents known to produce harmful side effects on prolonged use, herbal extracts are becoming popular and used in various formulations [6]. A critical evaluation of the role of herbal toothpaste and non-herbal toothpaste is important to evaluate their reducing potentials. Various ayurvedic components that are eventually included in herbal toothpastes and are essential to know their role against the oral cavity microbes. This study aims to evaluate the reducing potential of herbal toothpastes in comparison with a nonherbal toothpaste.

\section{Material and Methods}

Ethical clearance was obtained by the Institutional Ethical Committee (NU/CEC/2019/0244). Seven types of medicated herbal toothpaste groups (numbered from 1 to 7 ) and one non-herbal tooth paste (group 8) used as a control were evaluated. All toothpaste groups were diluted with distilled water, filtered using Syringe filter (Nupore) of type NNSY25 with pore size 0.45 micron, and the clear solution was taken as a tooth paste test sample. The test samples were then taken in 5 different volumes 100, 200, 300, 400 and $500 \mu \mathrm{L}$ and tested for Redox potential. Estimation of Redox potential by DNPH method: The reducing power in all samples were evaluated by Dinitrophenylhydrazine (DNPH) method. Different concentrations of ascorbic acid (EMPARTA, Merck Life Sciences Pvt. Ltd. India) used as standard, as it undergoes reversible conversion to its oxidized form dehydroascorbic acid. Both these form a couple with 2,4-dinitrophenyl hydrazine (HIMEDIA, HiMedia Laboratories Pvt. Ltd. India) to yield an osazone, which gives yellow color with 4.5 M sulphuric acid. Copper in the DNPH reagent acts as a catalyst, and the intensity of the color was read at $520 \mathrm{~nm}$ [7]. 


\section{Statistical Analysis}

The data collected was entered into a Microsoft Excel spreadsheet and analyzed using IBM SPSS Statistics, Version 22(Armonk, NY: IBM Corp). Descriptive data were presented in the form of mean and Standard Deviation (SD). ANOVA test was used to compare the reducing potential between all eight toothpastes, respectively. The p-value less than 0.05 was considered as statistically significant.

\section{Results}

Comparison of Redox potential at different concentrations (100, 200, 300, 400 and $500 \mu 1)$ within each studied group and between different groups were conducted by repeated-measures ANOVA test (table 2 and 3 ) and the p-value $<0.05$ was considered statistically significant.

Comparison between different concentrations within the same toothpaste group was presented in Table 2. From Table 2, it can be interpreted that group 3 (Dabur Dant Rakshak) at concentration $100 \mu \mathrm{L}$ showed a mean value of 2.69 with SD 0.04 . At $200 \mu \mathrm{L}$ it showed a mean value of 2.98 with SD 0.06. At $300 \mu \mathrm{L}$ it showed a mean value of 3.50 with SD 0.10. At 400 $\mu \mathrm{L}$ it showed a mean value of 3.93 with SD 0.11 . At $500 \mu \mathrm{L}$ it showed a highest mean value of 4.46 with SD 0.11 compared to all other concentrations. The p-value $(<0.001 *)$ obtained was statistically significant.

Comparison between eight toothpaste groups (Table 3) showed that, group 3 (Dabur Dant rakshak) has the highest reducing power followed by group 5 (Patanjali Dantkanti), group 2 (Dabur red gel), group 1 (Dabur Red toothpaste), group 6 (Colgate Swarna Vedshakti), group 4 (Dabur babool ayurvedic), group 7 (Dabur meswak) and the least was observed in group 8 (colgate strong teeth) and the results obtained were statistically significant ( $\mathrm{p}<0.001 *$ )

\begin{tabular}{|c|c|c|}
\hline Groups & Toothpastes & Composition \\
\hline 1. & $\begin{array}{c}\text { Dabur red } \\
\text { (Dabur } \\
\text { India Ltd.) }\end{array}$ & $\begin{array}{c}\text { Herbal extracts derived from Maricha, pippali, Shunti, Tomar, Lavang, } \\
\text { Karpura, Pudina, Garlic powder, preservative, and xcipients }\end{array}$ \\
\hline 2. & $\begin{array}{c}\text { Dabur red } \\
\text { gel } \\
\text { (Dabur } \\
\text { India Ltd.) }\end{array}$ & $\begin{array}{c}\text { Herbal extracts derived from Maricha, Pippali, Shunti, Tomar, Karpura, } \\
\text { Pudina satva, Lavang oil, preservative, and excipients (gel base). }\end{array}$ \\
\end{tabular}




\begin{tabular}{|c|c|c|}
\hline 3. & $\begin{array}{l}\text { Dabur Dant } \\
\text { rakshak } \\
\text { (Dabur } \\
\text { India Ltd.) }\end{array}$ & $\begin{array}{l}\text { Herbal extracts derived from Mulathee, Ajwain, Pudina Satva, Pudina } \\
\text { oil, Babul, Manjista, Dalchini, Khair, Patang, Kababchini, Jambhul, } \\
\text { Majuphal, Ber, Vajradanti, Tejbal, Lavangoil, Anantmool, Bakul, } \\
\text { Beheda, Dadim, Peelu, Nilgiri, Sonf, Akarkara, Neem, Maricha, Pippali, } \\
\text { Shunti, Badam, Elaichi, Garlic powder preservative, and excipients. }\end{array}$ \\
\hline 4. & $\begin{array}{l}\text { Dabur } \\
\text { Babool } \\
\text { ayurvedic } \\
\text { (Dabur } \\
\text { India Ltd.) }\end{array}$ & $\begin{array}{l}\text { Herbal extracts derived from Babul, Triphala, Pudina, Lavang, Pudina } \\
\text { satva, Patchouli oil, Kaolin, preservative and excipients. }\end{array}$ \\
\hline 5. & $\begin{array}{l}\text { Patanjali } \\
\text { Dantkanti } \\
\text { (Patanjali } \\
\text { Ayurved } \\
\text { Ltd. India) }\end{array}$ & $\begin{array}{c}\text { Akarkara, Neem, Babool, Pudina, Long bud, Tomar, Haldi, Pilu, Bakul, } \\
\text { Vidang }\end{array}$ \\
\hline 6. & $\begin{array}{l}\text { Colgate } \\
\text { Swarna } \\
\text { Vedshakti } \\
\text { (Colgate } \\
\text { Palmolive } \\
\text { India Ltd.) }\end{array}$ & $\begin{array}{l}\text { Calcium Cabonate, Sorbitoal, Sodium Lauryl Sulfate, Silica, Zinc } \\
\text { Oxide, Sodium Silicate, Carrageenan, Sodium monoflurophosphate, } \\
\text { Flavor, Zinc Citrate Trihydrate, Sodium bicarbonate, Benzyl alcohol, } \\
\text { Potassium Nitrate, Sodium Saccharin, Camphor, Mint Oil, Amla } \\
\text { Extract, Neem Seed Oil, Aloe Vera Extract, Cinnamon Leaf Oil, Basil } \\
\text { Oil, Fennel Oil, Honey Extract, Eugenol, d-Limonene in aqueous base. }\end{array}$ \\
\hline 7. & $\begin{array}{l}\text { Dabur } \\
\text { Meswak } \\
\text { (Dabur } \\
\text { India Ltd.) }\end{array}$ & $\begin{array}{l}\text { Calcium Carbonate, Sorbitol, Water, Silica, Sodium Lauryl Sulphate, } \\
\text { Flavour, Meswak extract, Cellulose, Gum, Carrageenan, Sodium } \\
\text { silicate, Sodium Silicate, PVM/MA Copolymer, Sodium Saccharin, Zinc } \\
\text { Gluconate, Sodium Benzoate, Cl 77891, Benzyl Alcohol, p-Thymol }\end{array}$ \\
\hline 8. & $\begin{array}{l}\text { Colgate } \\
\text { Strong teeth } \\
\text { (Colgate } \\
\text { Palmolive } \\
\text { United } \\
\text { States) }\end{array}$ & $\begin{array}{l}\text { Calcium carbonate, Sorbitol, Sodium lauryl sulfate, Silica, Titanium } \\
\text { dioxide, Sodium silicate, flavor, Carrageenan, Sodium } \\
\text { monoflurophosphate, Sodium bicarbonate, Benzyl alcohol, Sodium } \\
\text { saccharin, triclosan, in aqueous base }\end{array}$ \\
\hline
\end{tabular}

Table 1: The composition of the medicated herbal and non -herbal toothpastes.

\begin{tabular}{|c|c|c|c|c|c|}
\hline \multirow{2}{*}{ Study Group } & \multirow{2}{*}{ Concentration } & \multirow{2}{*}{ Mean } & \multirow{2}{*}{ SD } & \multicolumn{2}{|c|}{ Repeated Measures ANOVA } \\
\cline { 4 - 5 } & & & & $\mathbf{F}$ & p-value \\
\hline \multirow{3}{*}{1} & 100 & 2.30 & 0.04 & \multirow{2}{*}{515.13} & $<0.001^{*}$ \\
\cline { 2 - 4 } & 200 & 2.51 & 0.05 & & \\
\cline { 2 - 4 } & 300 & 2.83 & 0.07 & & \\
\hline
\end{tabular}




\begin{tabular}{|c|c|c|c|c|c|}
\hline & 400 & 3.22 & 0.10 & & \\
\hline & 500 & 3.54 & 0.04 & & \\
\hline \multirow{5}{*}{2} & 100 & 2.17 & 0.08 & \multirow{5}{*}{760.74} & \multirow{5}{*}{$<0.001 *$} \\
\hline & 200 & 2.50 & 0.04 & & \\
\hline & 300 & 2.76 & 0.05 & & \\
\hline & 400 & 3.02 & 0.05 & & \\
\hline & 500 & 3.64 & 0.05 & & \\
\hline \multirow{5}{*}{3} & 100 & 2.69 & 0.04 & \multirow{5}{*}{440.48} & \multirow{5}{*}{$<0.001 *$} \\
\hline & 200 & 2.98 & 0.06 & & \\
\hline & 300 & 3.50 & 0.10 & & \\
\hline & 400 & 3.93 & 0.11 & & \\
\hline & 500 & 4.46 & 0.11 & & \\
\hline \multirow{5}{*}{4} & 100 & 1.81 & 0.06 & \multirow{5}{*}{360.65} & \multirow{5}{*}{$<0.001^{*}$} \\
\hline & 200 & 2.13 & 0.12 & & \\
\hline & 300 & 2.60 & 0.05 & & \\
\hline & 400 & 2.84 & 0.04 & & \\
\hline & 500 & 3.16 & 0.12 & & \\
\hline \multirow{5}{*}{5} & 100 & 2.20 & 0.06 & \multirow{5}{*}{729.61} & \multirow{5}{*}{$<0.001 *$} \\
\hline & 200 & 2.77 & 0.04 & & \\
\hline & 300 & 3.07 & 0.07 & & \\
\hline & 400 & 3.40 & 0.04 & & \\
\hline & 500 & 3.71 & 0.08 & & \\
\hline \multirow{5}{*}{6} & 100 & 2.17 & 0.05 & \multirow{5}{*}{753.63} & \multirow{5}{*}{$<0.001 *$} \\
\hline & 200 & 2.60 & 0.05 & & \\
\hline & 300 & 2.86 & 0.04 & & \\
\hline & 400 & 3.21 & 0.08 & & \\
\hline & 500 & 3.45 & 0.04 & & \\
\hline \multirow{5}{*}{7} & 100 & 1.53 & 0.07 & \multirow{5}{*}{735.66} & \multirow{5}{*}{$<0.001^{*}$} \\
\hline & 200 & 2.11 & 0.06 & & \\
\hline & 300 & 2.22 & 0.08 & & \\
\hline & 400 & 2.50 & 0.05 & & \\
\hline & 500 & 3.06 & 0.05 & & \\
\hline \multirow{5}{*}{8} & 100 & 1.35 & 0.06 & \multirow{5}{*}{1003.57} & \multirow{5}{*}{$<0.001 *$} \\
\hline & 200 & 1.69 & 0.06 & & \\
\hline & 300 & 1.96 & 0.06 & & \\
\hline & 400 & 2.47 & 0.04 & & \\
\hline & 500 & 2.73 & 0.05 & & \\
\hline
\end{tabular}

Table 2: Comparison of Redox potential at different concentration within each study group. 


\begin{tabular}{|c|c|c|c|c|c|c|c|}
\hline \multirow{2}{*}{ Concentration } & \multirow{2}{*}{ Study groups } & \multirow{2}{*}{ Mean } & \multirow{2}{*}{ SD } & \multirow{2}{*}{ Min } & \multirow{2}{*}{$\operatorname{Max}$} & \multicolumn{2}{|c|}{ ANOVA } \\
\hline & & & & & & $\mathbf{F}$ & p-value \\
\hline \multirow{8}{*}{100} & 1 & 2.30 & 0.04 & 2.25 & 2.38 & \multirow{8}{*}{434.48} & \multirow{8}{*}{$<0.001 *$} \\
\hline & 2 & 2.17 & 0.08 & 2.05 & 2.30 & & \\
\hline & 3 & 2.69 & 0.04 & 2.63 & 2.75 & & \\
\hline & 4 & 1.81 & 0.06 & 1.72 & 1.88 & & \\
\hline & 5 & 2.20 & 0.06 & 2.14 & 2.30 & & \\
\hline & 6 & 2.17 & 0.05 & 2.12 & 2.24 & & \\
\hline & 7 & 1.53 & 0.07 & 1.44 & 1.64 & & \\
\hline & 8 & 1.35 & 0.06 & 1.27 & 1.44 & & \\
\hline \multirow{8}{*}{200} & 1 & 2.51 & 0.05 & 2.44 & 2.59 & \multirow{8}{*}{341.67} & \multirow{8}{*}{$<0.001 *$} \\
\hline & 2 & 2.50 & 0.04 & 2.43 & 2.54 & & \\
\hline & 3 & 2.98 & 0.06 & 2.90 & 3.06 & & \\
\hline & 4 & 2.13 & 0.12 & 1.92 & 2.28 & & \\
\hline & 5 & 2.77 & 0.04 & 2.71 & 2.84 & & \\
\hline & 6 & 2.60 & 0.05 & 2.53 & 2.67 & & \\
\hline & 7 & 2.11 & 0.06 & 2.04 & 2.21 & & \\
\hline & 8 & 1.69 & 0.06 & 1.60 & 1.78 & & \\
\hline \multirow{8}{*}{300} & 1 & 2.83 & 0.07 & 2.72 & 2.92 & \multirow{8}{*}{399.15} & \multirow{8}{*}{$<0.001 *$} \\
\hline & 2 & 2.76 & 0.05 & 2.69 & 2.83 & & \\
\hline & 3 & 3.50 & 0.10 & 3.30 & 3.62 & & \\
\hline & 4 & 2.60 & 0.05 & 2.52 & 2.68 & & \\
\hline & 5 & 3.07 & 0.07 & 3.00 & 3.21 & & \\
\hline & 6 & 2.86 & 0.04 & 2.80 & 2.95 & & \\
\hline & 7 & 2.22 & 0.08 & 2.09 & 2.31 & & \\
\hline & 8 & 1.96 & 0.06 & 1.89 & 2.04 & & \\
\hline \multirow{8}{*}{400} & 1 & 3.22 & 0.10 & 3.06 & 3.35 & \multirow{8}{*}{381.88} & \multirow{8}{*}{$<0.001 *$} \\
\hline & 2 & 3.02 & 0.05 & 2.95 & 3.09 & & \\
\hline & 3 & 3.93 & 0.11 & 3.79 & 4.09 & & \\
\hline & 4 & 2.84 & 0.04 & 2.79 & 2.91 & & \\
\hline & 5 & 3.40 & 0.04 & 3.34 & 3.46 & & \\
\hline & 6 & 3.21 & 0.08 & 3.06 & 3.32 & & \\
\hline & 7 & 2.50 & 0.05 & 2.44 & 2.61 & & \\
\hline & 8 & 2.47 & 0.04 & 2.42 & 2.52 & & \\
\hline \multirow{5}{*}{500} & 1 & 3.54 & 0.04 & 3.48 & 3.60 & \multirow{5}{*}{403.51} & \multirow{5}{*}{$<0.001 *$} \\
\hline & 2 & 3.64 & 0.05 & 3.57 & 3.71 & & \\
\hline & 3 & 4.46 & 0.11 & 4.30 & 4.65 & & \\
\hline & 4 & 3.16 & 0.12 & 3.00 & 3.32 & & \\
\hline & 5 & 3.71 & 0.08 & 3.58 & 3.83 & & \\
\hline
\end{tabular}






Table 3: Comparison of Redox potential between the studied groups with different concentrations.

\section{Discussion}

Pathogenic bacteria play an important role in the formation of biofilms. The bacterial accumulation in a biofilm on the tooth surface initiates the periodontitis. Periodontitis is a multifactorial disease that encompasses the hard and soft tissue, microbial colonization (with or without invasion), inflammatory responses and adaptive immune responses. Periodontal disease is classified into 2 types: gingivitis and periodontitis. Gingivitis is characterized by inflammation limited to the gingiva, whereas periodontitis is a progressive, destructive disease that affects all supporting tissues of the teeth, including the alveolar bone [8].

The prevalence of periodontitis of mild to moderate type was nearly $25 \%$, while severe type was only $17 \%$. The prevalence of gingivitis is $49 \%$ [9].

The increase bacterial metabolism in the oral cavity lowers the oxidation and reduction potential. Periodontal pockets have a much lower redox potential than healthy gingival sulci. The changes in the bacterial population that occurs as plaque develops on a fresh surface is due to the fall in redox potential [10].

These days there is an increased public interest in the usage of alternative health care, including the use of natural or herbal healthcare products. Toothpastes have been used since ancient times and are one of the main irreplaceable components of oral health care. Toothpaste is mainly used to promote oral cleanliness and it also acts as an abrasive that helps to prevent the dental plaque and eliminate food particles from the teeth, aids in the removing and/or veiling of halitosis, and releases active ingredients such as fluoride to aid in preventing tooth and gum disease. The majority of the cleaning is performed by the mechanical utilization of the toothbrush with the help of excipients used in toothpaste. Herbal toothpastes have an emphasizing role in maintaining the oral health.

The herbal dentifrices do not cause any adverse effects on the oral cavity and effectively reduce plaque and gingivitis, as that of fluoridated non-herbal dentifrices. Hence, medicated herbal toothpastes can be safely used to control plaque and gingivitis [11]. 
Based on the results and conclusions drawn, among all groups of toothpastes the group 3 (Dabur dant rakshak) showed the highest redox potential followed by group 5 (Patanjali Dantkanti), group 2 (Dabur red gel), group 1 (Dabur Red toothpaste), group 6 (Colgate Swarna Vedshakti), group 4 (Dabur babool ayurvedic), group 7 (Dabur meswak) and the least was observed in non- herbal group 8 (Colgate Strong teeth). The ingredients like Pudina, Babul, Manjista, Dalchini, Kababchini, Jambhul, Beheda, Dadim, Neem and Garlic present in group 3 toothpaste are rich in antioxidants, thereby enhancing the redox potential in the toothpaste.

\section{Conclusion}

The present study concludes that increase in redox potential prevents propagation of oral microbes. The medicated toothpaste namely Dabur dant rakshak showed the highest redox potential, compared to other groups. Therefore, it could be used for the prevention of dental caries, periodontitis and gingivitis as well as to maintain the health of oral tissues. A further in-vivo study is required to assess the antiplaque, antibacterial, antiviral, anti-gingival, anticariogenic, and healing of oral lesions capacity of medicated toothpastes.

\section{Acknowledgment}

The authors appreciate the assistance provided by the Central Research Laboratory, K. S. Hegde Medical Academy, Nitte University, Deralakatte, Mangalore, India.

\section{References}

1. Dewhirst FE, Chen T, Izard J, Paster BJ, Tanner AC, Yu WH, Lakshmanan A, Wade WG. The human oral microbiome. J Bacteriol. 2010;192(19):5002-17.

2. Prasanth M. Antimicrobial efficacy of different toothpastes and mouthrinses: an in-vitro study. Dental Res J. 2011;8(2):85.

3. Marsh PD, Bradshaw DJ. Physiological approaches to the control of oral biofilms. Adv Dental Res. 1997;11(1):176-85.

4. Sharma GN, Gupta G, Sharma P. A comprehensive review of free radicals, antioxidants and their relationship with human ailments. Critical Reviews ${ }^{\text {TM }}$ in Eukaryotic Gene Expression. 2018;28(2).

5. Fusco D, Colloca G, Monaco MRL, Cesari M. Effects of antioxidant supplementation on the aging process. Clinical Interventions Aging. 2007;2(3):377.

6. Shaheen SS, Reddy P, Hemalatha SR, Doshi D, Kulkarni S, Kumar M. Antimicrobial efficacy of ten commercially available herbal dentifrices against specific oral microflora- In-vitro study. J Clin Diagnostic Res-JCDR. 2015;9(4):ZC42.

7. Hegde MN, Kumari S, Hegde ND, Shetty SS. Relation between salivary and serum vitamin c levels and dental caries experience in adults-ab ochemical study. J Health Allied Sci NU. 2013;3(4):30-3.

8. Gupta G. Probiotics and periodontal health. J Medicine Life. 2011;4(4):387.

9. Janakiram C, Venkitachalam R, Mehta A. Prevalence of periodontal disease among adults in India: A systematic review and meta-analysis. J Oral Biol Craniofacial Res. 2020. 
10. Kenney EB, Ash Jr MM. Oxidation reduction potential of developing plaque, periodontal pockets and gingival sulci. J Periodontology-Periodontics. 1969;40(11):630-3.

11. Tatikonda A, Debnath S, Chauhan VS, Chaurasia VR, Taranath M, Sharma AM. Effects of herbal and nonherbal toothpastes on plaque and gingivitis: A clinical comparative study. J Int Society Prev and Comm Dentistry. 2014;4(2):S126. 